${ }^{21}$ Düsterdieck G, McElwee G. Estimation of angiotensin II concentrations in human plasma: some applications to physiological and clinical states. Eur $\mathcal{F}$ Clin Invest $1971 ; 2: 32-8$

${ }^{22}$ Fraser R, Guest S, Young J. Comparison of double isotope derivative and radio-immunological estimation of plasma aldosterone concentration. Clinical Science and Molecular Medicine 1973;45:411-5.

23 Waite MA. Measurement of concentrations of angiotensin I in human blood by radioimmunoassay. Clinical Science and Molecular Medicine $1973 ; 45: 51-64$

24 Atkinson AB, Morton JJ, Brown JJ, et al. Captopril in clinical hypertension: changes in components of the renin-angiotensin system and in body composition in relation to the fall in blood pressure with a note on the measurement of angiotensin II during converting enzyme inhibition. Br Heart $\mathcal{F} 1980 ; 44: 290-6$

${ }^{25}$ Davies DL, Robertson JWK. Simultaneous measurement of total exchangeable potassium and sodium using ${ }^{43} \mathrm{~K}$ and ${ }^{24} \mathrm{Na}$. Metabolism $1973 ; 22: 133-7$

${ }^{26}$ Boddy K, King PC, Tothill P, Strong JA. Measurement of total body potassium with a shadow shield whole-body counter: calibration and errors. Phys Med Biol $1971 ; 16: 275-82$.
27 Brown JJ, Davies DL, Lever AF, Robertson JIS. Renin and angiotensin: a survey of some aspects. Postgrad Med 7 1966;42:153-76.

${ }^{28}$ Atkinson AB, Brown JJ, Lever AF, et al. Neurological dysfunction in two patients receiving captopril and cimetidine. Lancet 1980 ;ii:36-7.

${ }^{29}$ Berlyne GM, Tavill AS, Baker SBdeC. Renal artery stenosis and the nephrotic syndrome. $Q \mathcal{F}$ Med $1964 ; 33: 325-35$.

${ }^{30}$ Atlas SA, Case DB, Sealey JE, Laragh JH, McKinstry DK. Interruption of the renin-angiotensin system in hypertensive patients by captopril induces sustained reduction in aldosterone secretion, potassium retention and natriuresis. Hypertension $1979 ; 1: 274-80$.

${ }^{31}$ Brown JJ, Peart WS. The effect of angiotensin on urine flow and electrolyte excretion in hypertensive patients. Clin Sci 1962;22:1-17.

${ }^{32}$ Brown JJ, Matthew GK, Robertson JIS. The effect of angiotensin on the function of the separate kidneys in patients with unilateral renal artery stenosis. Clin Sci $1964 ; 26: 381-95$.

33 Selkurt EE. Effect of pulse pressure and mean arterial pressure modification on renal hemodynamics and electrolyte and water concentration. Circulation $1951 ; 4: 541-6$.

(Accepted 13 November 1981)

\title{
Captopril in essential hypertension; contrasting effects of adding hydrochlorothiazide or propranolol
}

\author{
GRAHAM A MACGREGOR, NIRMALA D MARKANDU, RICHARD A BANKS, JOHN BAYLISS, \\ JOSEPH E ROULSTON, JULIA C JONES
}

\begin{abstract}
Twenty-four patients with moderate to severe hypertension were treated for four weeks with captopril, an oral inhibitor of angiotensin-converting enzyme. The fall in blood pressure with captopril alone correlated with pretreatment plasma renin activity. The effect of adding either hydrochlorothiazide or propranolol to the captopril treatment was then studied. The addition of hydrochlorothiazide to captopril produced a dosedependent fall in blood pressure. At the higher dose of the diuretic this fall in blood pressure correlated with weight loss, suggesting that when the diuretic-induced compensatory rise in angiotensin II is prevented by captopril the fall in blood pressure becomes dependent on loss of sodium and water. In contrast, the addition of propranolol to captopril produced no further fall in blood pressure, suggesting that inhibition of angiotensinconverting enzyme prevents the blood pressure lowering effect of propranolol. This may have implications for the mechanism whereby beta-blockers alone lower blood pressure.
\end{abstract}

These contrasting effects of hydrochlorothiazide and propranolol in the presence of captopril indicate that in patients whose hypertension is not controlled by captopril

\footnotetext{
Department of Medicine, Charing Cross Hospital Medical School, Blood Pressure Unit, London W6 8RF

GRAHAM A MACGREGOR, MA, MRCP, senior lecturer

NIRMALA D MARKANDU, sRN, research assistant

RICHARD A BANKS, BSC, MRCP, research fellow (now senior registrar in nephrology, Southmead Hospital, Bristol BS10)

JOHN BAYLISS, MA, MRCP, research fellow (now medical registrar, Hillingdon Hospital, Uxbridge, Middlesex)

JOSEPH E ROULSTON, MA, PHD, senior biochemist (now lecturer in biochemistry, Department of Clinical Chemistry, Royal Infirmary, Edinburgh EH3 9YW)

JULIA C JONES, BSC, MSC, biochemist
}

alone the addition of increasing doses of diuretic is likely to control the blood pressure. The addition of a betablocker, however, is less likely to be effective.

\section{Introduction}

Inhibition of the angiotensin-converting enzyme is an effective way of lowering blood pressure, ${ }^{1-3}$ but acceptable blood pressure control is not always obtained by inhibiting converting enzyme alone, especially in patients with severe hypertension and low renin. ${ }^{45}$ On theoretical grounds the addition of a diuretic to captopril should be particularly effective, as captopril will block the compensatory rise in angiotensin II caused by the diuretic. ${ }^{6-8}$ The addition of a beta-blocker to captopril may not, however, be as effective as the combination of captopril and a diuretic.

In two carefully controlled clinical trials we therefore examined the effects of adding either a thiazide diuretic (hydrochlorothiazide) or a beta-blocker (propranolol) in patients with moderate to severe essential hypertension already receiving captopril. These trials were done before it was known that captopril may very rarely cause leucopenia. Captopril is now recommended by the manufacturers only in patients who are resistant to conventional drug treatment or who have severe side effects with conventional treatment.

\section{Patients and methods}

Patients with uncomplicated moderate to severe essential hypertension were studied. Patients were excluded if there was evidence of reıal failure, ischaemic heart disease, or cerebrovascular disease or if they were taking oral contraceptives or any other drug. Informed consent was obtained from each patient. Patients had either not received treatment for their blood pressure or, if they had, treatment had been stopped at least two weeks before entry to the study.

There were two separate studies. In the first captopril and hydrochlorothiazide were given to 16 patients ( 9 men, 7 women; 12 blacks and 4 whites; mean age 52 years (range 42-61)) with moderate to severe hypertension (mean supine diastolic blood pressure $121 \mathrm{~mm} \mathrm{Hg}$ 
(range 104-140)). In the second study captopril and propranolol were given to eight patients ( 5 men, 3 women; 1 black, 7 whites; mean age 53 years (range 43-65)) with moderate hypertension (mean supine diastolic blood pressure $113 \mathrm{~mm} \mathrm{Hg}$ (range 105-121))

In the first study captopril was given thrice daily, $25 \mathrm{mg}$ for one week, $50 \mathrm{mg}$ for the second week, $100 \mathrm{mg}$ for the third week, and $150 \mathrm{mg}$ for the fourth week. Hydrochlorothiazide $25 \mathrm{mg}$ twice daily was then added to captopril for two to four weeks. In 11 patients in whom the diastolic pressure was still greater than $95 \mathrm{~mm} \mathrm{Hg}$ hydrochlorothiazide $50 \mathrm{mg}$ twice daily was given with captopril for a further four to six weeks.

In the second study the eight patients received four weeks of matching placebo before starting captopril. The treatment period with captopril alone was identical to that in the first study, increasing weekly from $25 \mathrm{mg}$ three times a day in the first week to $150 \mathrm{mg}$ three times a day in the fourth. Propranolol $20 \mathrm{mg}$ three times a day was then added for a fifth week. Two patients experienced adverse effects at this stage and treatment was stopped. In the remaining six patients the dose of propranolol was increased to $40 \mathrm{mg}$ three times a day in the sixth week. One other patient developed a, side effect and was withdrawn, allowing five patients to continue to the seventh week with propranolol $80 \mathrm{mg}$ three times a day in addition to captopril.

All patients were seen weekly in the blood pressure clinic at the same time of day by the same nurse. Patients were told to take their tablets two to three hours before visits so that measurements were done within two to four hours after the last dose of captopril. All blood pressures were measured with semi-automatic ultrasound sphygmomanometers (Arteriosonde 1217) with chart recorders. The measurement was therefore free of observer bias. We used the mean value of five readings taken at 1 - to 2 -minute intervals with the patient supine and standing. Pulse rate was measured on a Cambridge 3048 pulse monitor. Weight was measured at each visit.

Blood samples for estimating plasma renin activity and plasma aldosterone, urea, electrolyte, and creatinine concentrations were taken before active treatment and every one or two weeks thereafter. Blood was taken without stasis after the patient had been sitting upright for five minutes. Plasma renin activity ${ }^{9}$ and aldosterone ${ }^{10}$ were measured by radioimmunoassay. The normal ranges for plasma renin activity and plasma aldosterone with a sodium intake of 100-200 $\mathrm{mmol} /$ day are $0 \cdot 5-2.5 \mathrm{ng} / \mathrm{ml} / \mathrm{h}$ and $100-600 \mathrm{pmol} / \mathrm{l}$ respectively. All patients ate their normal diet, and their 24-hour urinary sodium excretion before treatment ranged from 104-190 $\mathrm{mmol}(\mathrm{mEq})$.

Mean arterial pressures were calculated as $1 / 3$ pulse pressure + diastolic pressure. Results were reported as means + SEM and were analysed by the paired Student's $t$ test and. least squares linear regression.

\section{Results}

\section{CAPTOPRIL AND HYDROCHLOROTHIAZIDE}

By the fourth week, when patients were taking only captopril 150 mg three times a day, mean blood pressure had fallen by $9 \%(p<0.05)$. The addition of hydrochlorothiazide $25 \mathrm{mg}$ twice a day produced a further fall ( $p<0.001$ compared to the last week of captopril alone), resulting in an overall reduction in mean supine blood pressure of $19 \%$ (fig 1). When hydrochlorothiazide was increased to $50 \mathrm{mg}$ twice a day there was a further fall in blood pressure $(p<0.001)$. The final supine blood pressure was $138 / 96 \pm 3 / 3 \mathrm{~mm} \mathrm{Hg}$, which represented an overall reduction in blood pressure of $25 \%$. Throughout the trial changes in standing blood pressures were similar to those of supine pressures. There was no evidence of postural hypotension.
Plasma renin activity before treatment was within the normal range in six patients and below the normal range in the other 10. Plasma renin activity increased by $0.83 \mathrm{ng} / \mathrm{ml} / \mathrm{h}(\mathrm{p}<0.005)$ after captopril 25 mg three times a day and remained significantly higher than the baseline value throughout treatment with captopril alone. Plasma renin activity rose further when hydrochlorothiazide was added to captopri (p<0.05; fig 1).

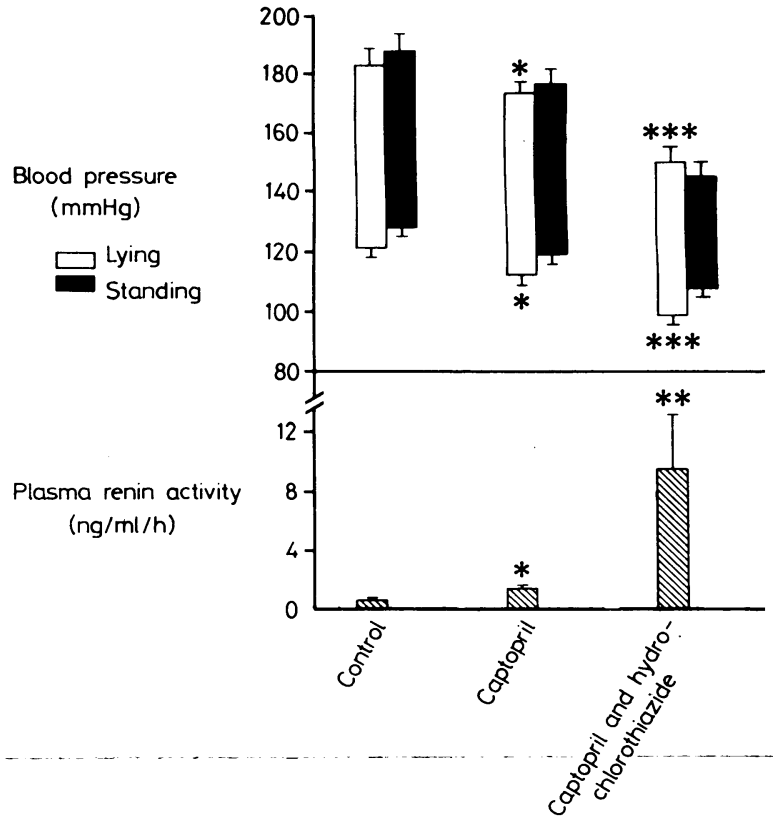

FIG 1-Blood pressure and plasma renin activity before treatment, after captopril $150 \mathrm{mg}$ three times a day, and after the addition of hydrochlorothiazide $25 \mathrm{mg}$ twice a day in 16 patients with moderate to severe hypertension. Values are means \pm SEM. ${ }^{*}$ p $<0.05$ compared to control; ${ }^{* *} p<0.01,{ }^{* * *} p \pm 0.001$ compared to captopril 150 mgthree times a day.

Mean plasma aldosterone concentrations fell, though not significantly, with captopril alone and did not rise after the addition of hydrochlorothiazide in spite of the rise in plasma renin activity. Mean body weight fell from 76.1 to $74.9 \mathrm{~kg}(\mathrm{p}<0.001)$ in the 16 patients when hydrochlorothiazide $25 \mathrm{mg}$ twice a day was added to captopril, and from 80.8 to $79.4 \mathrm{~kg}(\mathrm{p}<0.001$ ) in the 11 patients taking $50 \mathrm{mg}$ hydrochlorothiazide twice a day. The percentage fall in mean blood pressure after hydrochlorothiazide $50 \mathrm{mg}$ twice a day was added was significantly related to weight loss in these 11 patients $(r=0.64$; $\mathrm{p}<0.05)$. Plasma potassium concentrations fell from $4 \cdot 1$ to $3 \cdot 8$ $\mathrm{mmol}(\mathrm{mEq}) / \mathrm{l}$ after patients received $25 \mathrm{mg}$ hydrochlorothiazide twice a day in addition to captopril and from 4.1 to $3.5 \mathrm{mmol} / 1(\mathrm{p}<0.005)$ in the 11 patients after $50 \mathrm{mg}$ hydrochlorothiazide twice a day. Among these 11 patients the lowest final plasma potassium concentration was $2.8 \mathrm{mmol} / \mathrm{l}$, and five patients had a plasma potassium value below $3.5 \mathrm{mmol} / \mathrm{l}$ on the combination of captopril and $50 \mathrm{mg}$ hydrochlorothiazide twice a day (table I).

TABLE I-Effect of increasing doses of captopril and of adding hydrochlorothiazide to captopril 150 mg three times a day in 16 patients with moderate to severe hypertension. Values are means $\pm S E M$

\begin{tabular}{|c|c|c|c|c|c|c|c|}
\hline & \multirow{2}{*}{ Baseline } & \multicolumn{4}{|c|}{ Captopril (three times a day): } & \multicolumn{2}{|c|}{ Hydrochlorothiazide (twice a day): } \\
\hline & & $25 \mathrm{mg}$ & $50 \mathrm{mg}$ & $100 \mathrm{mg}$ & $150 \mathrm{mg}$ & $25 \mathrm{mg}(\mathrm{n}=16)$ & $50 \mathrm{mg}(\mathrm{n}=11)$ \\
\hline $\begin{array}{l}\text { Mean supine blood pressure }(\mathrm{mm} \mathrm{Hg}) \\
\text { Supine pulse rate/min } \\
\text { Weight loss }(\mathrm{kg}) \\
\text { Plasma aldosterone (pmol/1) } \\
\text { Plasma potassium (mmol/1) }\end{array}$ & $\begin{array}{rl}142 & +3 \\
81 & +3 \\
261 & 38 \\
3 \cdot 9 & 0 \cdot 1\end{array}$ & $\begin{array}{l}136 \pm 3 \\
78+3 \\
0 \cdot 2+0 \cdot 2 \\
246 \pm 33 \\
4 \cdot 0 \pm 0 \cdot 1\end{array}$ & $\begin{array}{l}142 \pm 4 \\
78+3 \\
0 \cdot 1+0 \cdot 2 \\
221+35 \\
3 \cdot 9+0 \cdot 1\end{array}$ & $\begin{array}{c:c}132 & 4^{*} \\
81 & 3 \\
0 \cdot 4 & 0 \cdot 2 \\
193 & 29 \\
4 \cdot 0 & 0 \cdot 1\end{array}$ & $\begin{array}{rl}129 & \pm 4^{*} \\
81 & 2 \\
0 \cdot 3 & 0 \cdot 3 \\
190 & 26 \\
4 \cdot 1 & 0 \cdot 1\end{array}$ & $\begin{array}{l}114 \pm 3 \ddagger \\
79 \pm 2 \\
1 \cdot 4 \pm 0 \cdot 3 \ddagger \\
229 \pm 39 \\
3 \cdot 8 \div 0 \cdot 1\end{array}$ & $\begin{array}{l}110 \pm 3 \ddagger \\
78 \pm 2 \\
1 \cdot 7 \pm 0 \cdot 5 \ddagger \\
170 \pm 19 \\
3 \cdot 5 \pm 0 \cdot 1 \dagger\end{array}$ \\
\hline
\end{tabular}

$* \mathrm{p}<0.05$ compared to control.

$\left.\begin{array}{l}\mathrm{p} \\ \pm \mathrm{p}<0.01\end{array}\right\}$ 0.001 $\}$ compared to captopril $150 \mathrm{mg}$ three times a day.

†onversion: SI to traditional units-Aldosterone: $1 \mathrm{pmol} / 1 \approx 36 \mathrm{pg} / 100 \mathrm{ml}$. Potassium: $1 \mathrm{mmol} / 1=1 \mathrm{mEq} / 1$. 
CAPTOPRIL AND PROPRANOLOL

Blood pressure did not change after four weeks of taking placebo. Mean blood pressure fell significantly after the first week of captopril $25 \mathrm{mg}$ three times a day. By the fourth week, when patients were taking $150 \mathrm{mg}$ captopril three times a day, mean supine blood pressure had fallen by $21 \%(\mathrm{p}<0.001)$. When propranolol $20 \mathrm{mg}$ three times a day was added diastolic and mean supine blood pressure rose significantly $(\mathrm{p}<0.005)$ (fig 2$)$. With $40 \mathrm{mg}$ propranolol three times a day blood pressure remained significantly raised $(156 / 99 \pm 7 / 4 \mathrm{~mm} \mathrm{Hg}$; $\mathrm{p}<0.025)$ and did not change in the five patients who received $80 \mathrm{mg}$ three times a day $(155 / 92 \pm 7 / 3 \mathrm{~mm} \mathrm{Hg})$.

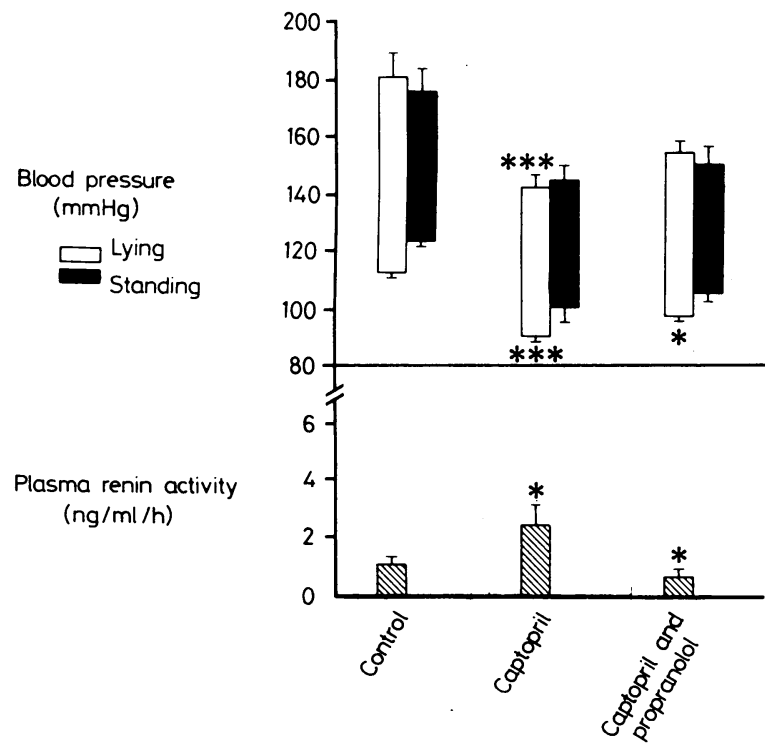

FIG 2-Blood pressure and plasma renin activity before treatment, after captopril $150 \mathrm{mg}$ three times a day, and after the addition of propranolol $20 \mathrm{mg}$ three times a day in eight patients with moderate hypertension. Values are means \pm SEM. ${ }^{* *} \mathrm{p}<0.01$ $* * * p<0.001$ compared to control; ${ }^{*} p<0.05$ compared to captopril $150 \mathrm{mg}$ three times a day. propranolol $20 \mathrm{mg}$ three times a day. Two were withdrawn at the end of the week on this combination and the third at the end of the week of captopril and propranolol $40 \mathrm{mg}$ three times a day. Taste sensation returned rapidly to all three when they stopped captopril. No patient developed proteinuria, rash, or leucopenia.

\section{Discussion}

The results of this study confirm that captopril alone lowers blood pressure in patients with moderate to severe essential hypertension. As others have found, ${ }^{2}{ }^{3}$ the fall in blood pressure with captopril alone was related to the activity of the reninangiotensin system before treatment. This could explain the smaller fall in blood pressure with captopril alone in patients who went on to receive hydrochlorothiazide, as they had more severe hypertension and a lower mean pretreatment plasma renin activity.

The addition of hydrochlorothiazide to captopril produced a pronounced further fall in blood pressure, and this fall was related to the dose of diuretic, in that there was a further fall in blood pressure in the 11 patients whose dose of hydrochlorothiazide was increased to $50 \mathrm{mg}$ twice a day. Several studies have suggested that the effectiveness of diuretics alone in reducing blood pressure is limited by the compensatory rise that occurs in plasma renin activity and thereby in plasma angiotensin II and aldosterone values. ${ }^{6-8}$ By inhibiting angiotensin-converting enzyme captopril will block the rise in plasma angiotensin II and aldosterone that normally occurs with the addition of hydrochlorothiazide. Blood pressure should then become dependent on sodium and water balance, ${ }^{5}$ analogous to the position in anephric subjects on dialysis. A fall in blood pressure with the addition of a diuretic to captopril should therefore be related to the loss of sodium and water caused by the diuretic, which would be reflected in the weight loss. The fact that plasma aldosterone did not rise with the addition of hydrochlorothiazide to captopril and the significant relationship between weight loss and the fall in blood pressure on $50 \mathrm{mg}$ of hydrochlorothiazide twice a day supports the above concept.

TABLE II-Effects of increasing doses of captopril and of adding propranolol 20 mg three times a day to captopril 150 mg three times a day in eight patients with moderate hypertension. Values are means \pm SEM

\begin{tabular}{|c|c|c|c|c|c|c|}
\hline & \multirow{2}{*}{ Baseline } & \multicolumn{4}{|c|}{ Captopril (three times a day): } & \multirow{2}{*}{$\begin{array}{c}\text { Captopril and } \\
\text { propranolol } 20 \mathrm{mg} \\
\text { three times a day }\end{array}$} \\
\hline & & $25 \mathrm{mg}$ & $50 \mathrm{mg}$ & $100 \mathrm{mg}$ & $150 \mathrm{mg}$ & \\
\hline $\begin{array}{l}\text { Mean supine blood pressure }(\mathrm{mm} \mathrm{Hg}) \\
\text { Supine pulse rate/min } \\
\text { Weight loss }(\mathrm{kg}) \\
\text { Plasma aldosterone (pmol/l) } \\
\text { Plasma potassium }(\mathrm{mmol} / \mathrm{l})\end{array}$ & $\begin{aligned} 136 & \pm 4 \\
78 & \pm 4 \\
295 & \pm 33 \\
3 \cdot 9 & \pm 0 \cdot 1\end{aligned}$ & $\begin{aligned} 122 & \pm 3 * * * \\
75 & \pm 4 \\
0 \cdot 6 & \pm 4 \\
194 & \pm 17 * * \\
3 \cdot 9 & \pm 0 \cdot 1\end{aligned}$ & $\begin{array}{l}119 \pm 4^{*} \\
76 \pm 5 \\
1 \cdot 1 \pm 0 \cdot 4^{*} \\
220 \pm 26^{*} \\
4 \cdot 1 \pm 0 \cdot 1\end{array}$ & $\begin{array}{l}116 \pm 3^{* *} \\
77 \pm 5 \\
1 \cdot 1 \pm 0 \cdot 5^{*} \\
188 \pm 19^{*} \\
4 \cdot 0 \pm 0 \cdot 2\end{array}$ & $\begin{array}{l}108 \pm 3^{* * *} \\
74 \pm \pm \\
1 \cdot 6 \pm 0 \cdot 5^{*} \\
202 \pm 26^{* *} \\
4 \cdot 1 \pm 0 \cdot 1\end{array}$ & $\begin{aligned} 117 & \pm 3 \dagger \\
64 & \pm 5 \dagger \\
1 \cdot 5 & \pm 0 \cdot 6 \\
184 & \pm 30 \\
4 \cdot 2 & \pm 0 \cdot 2\end{aligned}$ \\
\hline
\end{tabular}

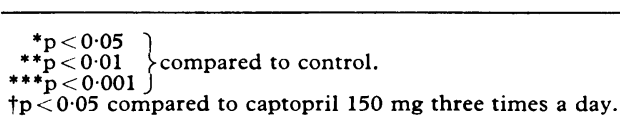

Plasma renin activity before active treatment was within the normal range in seven patients and low in one. Plasma renin activity rose by $0.89 \mathrm{ng} / \mathrm{ml} / \mathrm{h}(\mathrm{p}<0.001)$ after one week of captopril and remained at this level with increasing doses. When propranolol was added plasma renin activity fell in all patients $(p<0.005)$, and the resulting mean level was below the pretreatment control value (fig 2 ). Changes in mean blood pressure, pulse rate, weight, and plasma aldosterone and potassium concentrations with captopril alone and after the addition of propranolol are shown in table II.

When all the patients in both groups were considered together the percentage fall in mean blood pressure by the fourth week of treatment with captopril alone (150 mg three times a day) was significantly related to $\log$ initial plasma renin activity $(r=0.48, p<0.05, n=24)$.

\section{SIDE EFFECTS}

Captopril was well tolerated. Three patients, however, lost the sensation of taste after five weeks of captopril and one week of
It has been claimed that inhibition by captopril of the diuretic-induced rise in angiotensin II and aldosterone prevents the fall in plasma potassium concentration seen with diuretics alone. ${ }^{11}$ In our study, however, the addition of $50 \mathrm{mg}$ hydrochlorothiazide twice a day to captopril resulted in hypokalaemia in almost half the patients.

The effectiveness of the combination of captopril and a thiazide diuretic may be seen both by the percentage fall in blood pressure that occurred $(25 \%)$ and by the fact that of our patients with a mean pretreatment diastolic pressure of $122 \mathrm{~mm}$ $\mathrm{Hg}$ only two had a diastolic pressure of over $100 \mathrm{~mm} \mathrm{Hg}$ at the end of the trial. Our experience in 29 patients with treatmentresistant hypertension given captopril and a diuretic alone for more than six months supports other evidence ${ }^{12} 13$ that the combination of captopril and a diuretic alone is particularly effective in the long-term control of treatment-resistant hypertension. Many of the 29 patients with treatment-resistant 
hypertension did, however, need the addition of loop diuretics such as frusemide to induce the required loss of sodium and water.

In contrast to the effect of hydrochlorothiazide, the addition of propranolol to captopril produced a significant rise in blood pressure. All blood pressure measurements were, however, taken two to four hours after dosing, when captopril was likely to be exerting its maximum effect on blood pressure. In a similar study Lederle et $a l^{14}$ showed no significant change in blood pressure when propranolol was added to captopril. This may have some implications for the mechanism whereby betablockers alone lower blood pressure. It is of interest that a rise in blood pressure with propranolol alone has been seen in some patients with low-renin hypertension. ${ }^{15}$ Nevertheless, the addition of propranolol to captopril did cause a significant fall in pulse rate and reduced the captopril-induced high plasma renin activity to below pretreatment values. This latter observation shows that propranolol inhibits the increased renin release caused by captopril. Possibly propranolol, though inhibiting renin release, may prolong the length of action of captopril, so that if blood pressure was measured at a longer interval after dosing an apparent additive action of the two drugs might be seen.

In this short-term trial captopril was well tolerated, except for loss of taste in three patients, which recovered fully when they stopped taking captopril. The study does not indicate the minimum effective dose of captopril when combined with a diuretic. Our recent experience in patients with treatmentresistant hypertension given captopril suggests that much lower doses of captopril-that is, 12.5 to $25 \mathrm{mg}$ three times a day-are almost as effective as the larger doses used in this trial when combined with a diuretic. These lower doses might reduce the incidence of problems that have been seen with captopril, such as rash, loss of taste, ${ }^{16}$ membranous glomerulonephritis, ${ }^{17}$ and leucopenia in patients with renal failure. ${ }^{18}$ Inhibition of angiotensin-converting enzyme combined with a diuretic is likely to play an increasing part in the management of treatment-resistant hypertension and, if these drugs are shown to be well tolerated in the long term, an increasing part in the management of essential hypertension.

These studies were supported by the Wellcome Trust. We thank Dr P Piggott of Squibb, Europe, for supplies of captopril.

\section{References}

${ }^{1}$ Gavras H, Turini GA, Gavras I, et al. Antihypertensive effects of the oral angiotensin converting-enzyme inhibitor SQ 14225 in man. $N$ Engl f Med 1978;298:991-5.

2 Case DB, Atlas SA, Laragh JH, Sealey JE, Sullivan PA, McKinstry DN. Clinical experience with blockade of the renin-angiotensin-aldosterone system by an oral converting enzyme inhibitor (SQ14225, captopril) in hypertension patients. Prog Cardiovasc Dis 1978;21:195-206.

${ }^{3}$ MacGregor GA, Markandu ND, Roulston JE, Jones JC. Essential hypertension: effect of an oral inhibitor of angiotensin-converting enzyme. $B r$ Med $\mathcal{F} 1979$;ii:1106-9.

${ }^{4}$ Bravo EL, Tarazi RC. Converting enzyme inhibition with an orally active compound in hypertensive man. Hypertension 1979;1:39-46.

${ }^{5}$ Brunner HR, Wauters J, McKinstry D, Waeber B, Turini G, Gavras H. Inappropriate renin secretion unmasked by captopril (SQ14225) in hypertension of chronic renal failure. Lancet 1978;ii:704-7.

${ }^{6}$ MacGregor GA, Markandu ND, Roulston JE, Jones BE. The antihypertensive action of spironolactone: importance of the response of renin-angiotensin system to the loss of sodium and water. In: Addison GM, Asmussen N, Carol P, Kloppenborg PWC, Norman N, Schroder $\mathrm{R}$, Robertson JIS, eds. Aldosterone antagonists in clinical medicine. Amsterdam: Excerpta Medica, 1978:466-74

' Leonetti G, Terzoli L, Sala C, Bianchini C, Sernesi L, Zanchetti A Relationship between the hypotensive and renin-stimulating actions of diuretic therapy in hypertensive patients. Clin Sci Mol Med 1978;55 307S-9S.

${ }^{8}$ Ibsen H, Leth A, Hollnagel H, Kappelgaard AM, Kamkjaer Nielsen M, Giese J. Renin-angiotensin system in mild essential hypertension. The functional significance of angiotensin II in untreated and thiazidetreated hypertensive patients. Clin Sci Mol Med 1978;55:319S-21S.

${ }^{9}$ Roulston JE, MacGregor GA. Measurement of plasma renin activity by radioimmunoassay after prolonged cold storage. Clin Chim Acta 1978; 88:45-8.
${ }^{10}$ James VHT, Wilson GA. Determination of aldosterone in biological fluids. Methodological Developments in Biochemistry 1976;5:149-57.

${ }_{11}$ Johnston CI, McGrath BP, Millar JA, Matthews PG. Long-term effects of captopril (SQ 14225) on blood pressure and hormone levels in essential hypertension. Lancet 1979 ;ii:493-5.

12 Atkinson AB, Lever AF, Brown JJ, Robertson JIS. Combined treatment of severe intractable hypertension with captopril and diuretic. Lancet 1980;ii:105-7.

13 White NJ, Yahaya H, Rajagopalan B, Ledingham JGG. Captopril and frusemide in severe drug-resistant hypertension. Lancet 1980;ii:108-10.

14 Lederle RM, Klaus D, Braun B. Captopril bei essentieller hypertonie. Dtsch Med Wochenschr 1980;105:1307-12.

15 Drayer JIM, Keim HJ, Weber MA, Case DB, Laragh JH. Unexpected pressor responses to propranolol in essential hypertension: an interaction between renin, aldosterone and sympathetic activity. $\mathrm{Am} \mathcal{F} \mathrm{Med} 1976$; 60:897-903.

${ }^{16}$ Atkinson AB, Robertson JIS. Captopril in the treatment of clinical hypertension and cardiac failure. Lancet 1979; ii :836-9.

${ }^{17}$ Hoorntje SJ, Weening JJ, The TH, Kallenberg CGM, Donker AMD, Hoedemaeker PH. Immune complex glomerulopathy in patients treated with captopril. Lancet $1980 ; \mathrm{i}: 212-4$.

${ }^{18}$ Brummelen $\mathrm{P}$ van, Willemze $\mathrm{R}$, Tan WD, Thompson J. Captoprilassociated agranulocytosis. Lancet $1980 ; \mathrm{i}: 150$.

(Accepted 11 December 1981)

ONE HUNDRED YEARS AGO The profession will be grateful to the National Health Society for endeavouring to demonstrate the evils of tight lacing to popular audiences. I fear, however, that $\mathrm{Mr}$ Treves, in his recent lecture at Kensington, treated the subject a little too confidently from a sanitary and a little too cavalierly from an aesthetical, point of view. I should be very sorry if anything I said could be looked on as an encouragement to tight lacing by ladies; but still I think we should take them into our councils, and discuss the subject in all its bearings with moderation. I think that $\mathrm{Mr}$ Treves fell into an important error when he assumed that the primary use of dressing was to cover the body and maintain an equable temperature; and again, when he asserted that a small waist in a draped figure is ugly, and offends our sense of the beautiful in the human form. Now, all anthropologists agree that the primary object of dress was decoration, and this is still the only object of dress in probably a third of the human race. It is an instinct of which the physiologist takes no note, but nevertheless is as potent in High Street, Kensington, as in the centre of Africa or the provinces of North America. The decorative use of dress is not only a fact, but the first fact to be taken into consideration by reformers of the dress of the period. Again, it is idle to attempt to convince women that small waists are ugly, by comparing them with casts of nude figures of ideal proportions. Comparisons are odious, and this is a supremely odious one to women, and, moreover, a very unfair one; drape the figure, and see what becomes of its grand proportions. A custom which is so general must have some raison d'étre, although women cannot explain it. Some women think that men admire small waists; and, until the question is decided by a vote by ballot, they will not believe otherwise. In truth, small waists in draped figures are the result of the law of proportion, which is at the bottom of our sense of the beautiful, not only in the human form, but in all other objects. Professor Zeising, to whom we owe the discovery of this law, states it thus: "If the divisions of a whole (made up of unequal parts) appear proportional, the smaller part will bear the same relation to the larger that the larger does to the whole." Now the waist forms the division of the body which gives these proportions. Thus, if we take a well proportioned figure, and represent its total height by 1,000, we shall find the portion below the waist is represented by 618 , and the portion above it by 382 parts; and 382 is to 618 what 618 is to 1,000 . Zeising's law applies equally well to the hand, the head, the arm, and the leg; and, indeed, to all animate and inanimate objects which appear proportional to us. But in some nude figures, the proportional division is not at the waist, but at the knees. In the Venus de Medici, where the arms are folded across the body, this is the case; hence the charm of young girls with short skirts and no waists (and perhaps of men in frock coats). The shorter the skirts in children, the better the proportion appears; but as they grow up, and their skirts are lengthened, a new division line becomes necessary, and the waist is constricted accordingly. The dress reformers should, therefore, bear in mind that dressing is the instinct of decorating the body, and that a small waist is the result of a law of nature; but within these limits there is ample room for their efforts for improvement; many dresses are fantastic and in bad taste, and most waists are constricted too much even from an aesthetical point of view. (British Medical fournal, 1882.) 